\title{
Correction: Saritoprak, S.N. et al. 2018. Spiritual Jihad among U.S. Muslims: Preliminary Measurement and Associations with Well-Being and Growth. Religions 9: 158
}

\section{Seyma N. Saritoprak, Julie J. Exline *(D) and Nick Stauner $\mathbb{D}$}

Department of Psychological Sciences, Case Western Reserve University, Cleveland, OH 44106-7123, USA; seyma.saritoprak@case.edu (S.N.S.); nickstauner@gmail.com (N.S.)

* Correspondence: julie.exline@case.edu

The author wishes to make the following corrections to (Saritoprak et al. 2018):

Table 3. Summary of Exploratory Factor Analysis of the Spiritual Jihad Measure Using Ordinary Least Squares Estimation from a Polychoric Correlation Matrix and Direct Oblimin Rotation.

\begin{tabular}{|c|c|c|}
\hline \multicolumn{3}{|l|}{ Factor Loadings } \\
\hline Endorse SJM & & Reject SJM \\
\hline Omega Total Reliability & 0.91 & 0.82 \\
\hline The struggle is an opportunity for me to seeks Allah's forgiveness. & 0.63 & 0.07 \\
\hline I see the struggle as an opportunity to pray and ask Allah for guidance. & 0.77 & -0.04 \\
\hline The struggle is an opportunity for me to seeks Allah's forgiveness. & 0.76 & -0.04 \\
\hline I know that there is khair (good) in the struggle because there is khair (good) in everything Allah does. & 0.62 & -0.20 \\
\hline The struggle is an opportunity for me to seeks Allah's forgiveness. & 0.69 & -0.12 \\
\hline I tend to think that the struggle is for my best interest because Allah is al-Alim (All-Knowing). & 0.80 & 0.08 \\
\hline I believe the struggle is a way in which I can understand my imperfect nature. & 0.53 & -0.09 \\
\hline I do not view the struggle as means to become closer to Allah. & -0.19 & 0.58 \\
\hline
\end{tabular}

${ }^{1}$ Boldfaced text indicates items assigned to each factor.

with 
Table 3. Summary of Exploratory Factor Analysis of the Spiritual Jihad Measure Using Ordinary Least Squares Estimation from a Polychoric Correlation Matrix and Direct Oblimin Rotation.

\begin{tabular}{|c|c|c|}
\hline \multicolumn{3}{|l|}{ Factor Loadings } \\
\hline & Endorse SJM & Reject SJM \\
\hline Omega Total Reliability & 0.91 & 0.82 \\
\hline I have been thinking of my struggle as a desire of my nafs (soul/self) that I must work against. & 0.63 & 0.07 \\
\hline I see the struggle as an opportunity to pray and ask Allah for guidance. & 0.77 & -0.04 \\
\hline I view the struggle as means of earning more thawāb (good deeds) for the afterlife. & 0.79 & 0.16 \\
\hline I know that there is khair (good) in the struggle because there is khair (good) in everything Allah does. & 0.62 & -0.20 \\
\hline The struggle is an opportunity for me to seek Allah's forgiveness. & 0.69 & -0.12 \\
\hline I tend to think that the struggle is for my best interest because Allah is al-Alim (All-Knowing). & 0.80 & 0.08 \\
\hline I believe the struggle is a way in which I can understand my imperfect nature. & 0.53 & -0.09 \\
\hline I do not view the struggle as means to become closer to Allah. & -0.19 & 0.58 \\
\hline
\end{tabular}

${ }^{1}$ Boldfaced text indicates items assigned to each factor.

In Table 3, the item "The struggle is an opportunity for me to seek Allah's forgiveness" is repeated three times and the items "I have been thinking of my struggle as a desire of my nafs (soul/self) that I must work against" and "I believe that through this struggle, my iman (faith) will become stronger" are missing.

\section{Reference}

Saritoprak, Seyma N., Julie J. Exline, and Nick Stauner. 2018. Spiritual Jihad among U.S. Muslims: Preliminary Measurement and Associations with Well-Being and Growth. Religions 9: 158. [CrossRef]

2018 by the authors. Licensee MDPI, Basel, Switzerland. This article is an open access article distributed under the terms and conditions of the Creative Commons Attribution (CC BY) license (http://creativecommons.org/licenses/by/4.0/). 